\title{
ANALISIS PENGARUH STRATEGI OFFLINE TO ONLINE (O2O) TERHADAP PENJUALAN UMKM MITRA APLIKASI BadokanGresik.id
}

\author{
Alfista Firdaus ${ }^{1)^{*}}$, Raya Sulistyowati ${ }^{1)}$ \\ 1) Fakultas Ekonomika dan Bisnis, Universitas Negeri Surabaya \\ Penulis korespondensi: alfista.17080324068@mhs.unesa.ac.id, rayasulistyowati@unesa.ac.id
}

\begin{abstract}
Business strategies that MSMEs can implement in the digitization era is the Offline to Online (O2O) strategy. This study aims to analyze the influence of Offline to Online (O2O) strategy on the MSMEs sales of BadokanGresik.id application partners. This research is descriptive quantitative research. The sampling techniqueused is random sampling where the sample used is 62 MSME partners in the BadokanGresik.id application. The data collection technique used a questionnaire distributed with the help of Google Form. The hypothesis was tested using simple linear regression analysis processed with SPSS 25, including coefficient of determination test and $F$ test. The results of data analysis showed that partially, Offline to Online (O2O) strategy has a significant and positive effect on sales. Simultaneously, the Offline to Online (O2O) strategy has positively and significantly influence ales of MSMEs.
\end{abstract}

Keywords: Offline to Online, Sales, MSME

\section{Article Information:}

Received Date: 22 Juni 2021

Revised Date: 29 Juni 2021

Accepted Date: 1 Juli 2021 


\section{PENDAHULUAN}

Institute for Development Economy and Finance (INDEF) menyatakan bahwa tingkat pengangguran di Indonesia hingga akhir 2020 telah mencapai 7,8\% atau 10,4 juta jiwa. Data pengangguran nasional tersebut, sejalan dengan fenomena ketenagakerjaan yang terjadi di Kota Gresik. Berdasarkan data pengangguran terbuka di Kota Gresik, tercatat bahwa sebanyak $8,21 \%$ jiwa dari total penduduk Kota Gresik merupakan pengangguran. Angka tersebut mengalami peningkatan dari tahun 2019 yang mecapai $5,54 \%$ jiwa.

\section{Tabel 1. Perbandingan Komposisi} Ketenagakerjaan Kota Gresik

\begin{tabular}{|l|l|l|l|}
\hline Tahun & $\begin{array}{l}\text { Jumlah } \\
\text { Penduduk }\end{array}$ & $\begin{array}{l}\text { Angkatan } \\
\text { Kerja }\end{array}$ & $\begin{array}{l}\text { Pengangguran } \\
\text { Terbuka }\end{array}$ \\
\hline 2019 & 1.312 .881 & $65,65 \%$ & $5,54 \%$ \\
\hline 2020 & 1.311 .215 & $66,52 \%$ & $8,21 \%$ \\
\hline
\end{tabular}

Sumber: Kabupaten Gresik dalam Angka 2020

Peningkatan jumlah pengangguran terbuka tersebut disebabkan karena banyaknya perusahaan yang mengalami penurunan bahkan bangkrut sehingga harus memberhentikan para pekerja, tentu hal tersebut harus mendapatkan perhatian khusus dari pemerintah dan juga stakeholders. Pengangguran menyebabkan semakin meningkatnya jumlah penduduk miskin menjadi 164,05 ribu jiwa dan juga penurunan laju perekonomian Kota Gresik.

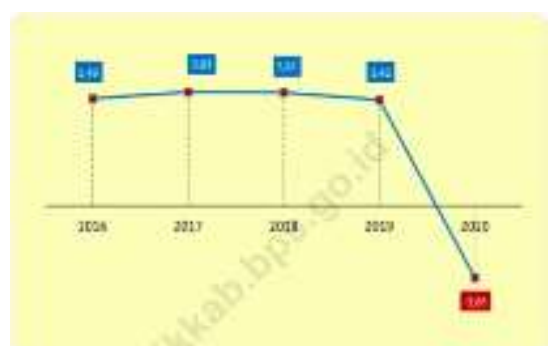

Sumber: gresikkab.bps.go.id

\section{Gambar 1. Laju Pertumbuhan Perekonomian Kota Gresik}

Pada gambar 1 ditunjukkan bahwa dari tahun 2016 hingga 2019, pertumbuhan perekonomian Kota Gresik stabil, namun mengalami penurunan yang drastis pada tahun 2020 yaitu sebesar $-3,68 \%$. Angka pengangguran dapat ditekan oleh pengembangan usaha didalam Kota Gresik, seperti pengembangan usaha kecil dan menengah yang berkontribusi terhadap terciptanya lapangan pekerjaan. Namun, berdasarkan data dari Badan Pusat Statistik disebutkan bahwa banyaknya UMKM yang tersebar di 18 kecamatan dan 330 desa, sejumlah 13.506 usaha mengalami dampak dari Covid-19 (Aslamiyah, 2021). Adapun sektor UMKM paling terdampak Covid-19 adalah sektor kuliner dikarenakan sistem penjualan yang masih mengandalkan tatap muka atau penjualan secara konvensional.

Penurunan penjualan UMKM salah satunya disebabkan oleh terjadinya fenomena The Network Effect yaitu pergeseran pola belanja masyarakat dari secara konvesional menjadi secara online. Fenomena tersebut didukung dengan ditetapkannya kebijakan social distancing oleh pemerintah Kota Gresik. Akibat adanya Perlakuan Pembatasan Kegiatan Masyarakat (PPKM), banyak UMKM yang harus gulung tikar karena tingkat penjualan yang sangat rendah. Pemanfaatan teknologi dalam berwirausaha dapat memberikan banyak kemudahan dalam melakukan kegiatan kewirausahaan, serta untuk meningkatkan usaha (Sulistyowati, 2020). Berbagai strategi digitalisasi dapat diterapkan oleh UMKM, salah satunya adalah strategi Offline to Online (O2O). O2O merupakan salah satu jenis model pemasaran yang terdapat di e-commerce. Electronic Commerce (E-Commerce) adalah usaha yang memanfaatkan teknologi untuk menaikkan tingkat penjualan, kemampuan bisnis dan memberikan acuan untuk produk dan layanan baru (Išoraitė \& Miniotienè, 2018).

$\mathrm{O} 2 \mathrm{O}$ mengkombinasikan usaha dengan basis offline dan online (Syafwendi, 2016). Strategi Offline to Online memiliki konsep menghadirkan toko fisik namun konsumen juga dapat melakukan transaksi secara online. 
Konsep tersebut bermakna luas, namun selama suatu kegiatan usaha yang masih melibatkan offline serta online, maka dapat dikategorikan sebagai O2O (Pradiani, 2018). Menurut pendapat dari Xing \& Zhu (2014), melalui Offline to Online, UMKM dapat memperkuat merek, menarik pasar, serta membangun hubungan dengan konsumen di momentum yang tepat sehingga mendukung pertumbuhan baru di lingkungan ekonomi. Selama bisnis dapat dikembangkan secara online dengan tetap menjalankan toko fisik (offline), maka dapat digolongkan sebagai $\mathrm{O} 2 \mathrm{O}$.

Penerapan strategi O2O pada UMKM di Kota Gresik didukung oleh aplikasi lokal yang diciptakan oleh pemuda Gresik. Melihat penurunan penjualan UMKM, pemuda Gresik berinisiatif menciptakan aplikasi pemasaran untuk membantu bangkitnya UMKM sektor kuliner di Kota Gresik. Implementasi strategi Offline to Online (O2O) pada UMKM dilakukan dengan cara UMKM tetap mempertahankan toko fisik (penjualan secara offline) dan juga menjalankan penjualan secara online. Dari hasil pengamatan peneliti yang dilakukan pada UMKM mitra aplikasi BadokanGresik.id, seluruh UMKM tetap mempertahankan penjualan offline meskipun telah menjalankan penjualan secara online. Dengan begitu, penjualan yang dihasilkan tidak hanya dari satu arah, melainkan dari dua arah (Offline dan Online).

Tujuan penelitian ini adalah menganalisis pengaruh strategi Offline to Online $(\mathrm{O} 2 \mathrm{O})$ terhadap penjualan UMKM sektor kuliner yang menjadi mitra aplikasi BadokanGresik.id.

\section{TINJAUAN PUSTAKA}

\section{Strategi Offline to Online (O2O)}

$\mathrm{O} 2 \mathrm{O}$ merupakan singkatan dari Offline to Online, yang mengacu pada sebuah peluang bisnis berbasis offline yang dikombinasikan dengan internet (online) (Syafwendi, 2016). Selain itu, O2O dapat diartikan sebagai penggunaan pemasaran online dan mendorong pembelian serta konsumsi offline, dan untuk memfasilitasi transaksi offline berbasis internet (Wang, 2020). Dari pemaparan definisi O2O di atas, dapat disimpulkan bahwa Offline to Online $(\mathrm{O} 2 \mathrm{O})$ adalah sebuah strategi bisnis yang mengkombinasikan online dalam memasarkan produk dan mendorong konsumen untuk melakukan transaksi pada toko fisik (offline). Selama bisnis dapat mengembangkan perdagangan secara online dengan tetap membuka toko fisik (Offline), maka dapat dikategorikan sebagai O2O (Xu \& Zhang, 2015).

Indikator strategi $O 2 O$ menurut (Xing \& Zhu, 2014) adalah (1) Build network platform, Kecanggihan teknologi dan meningkatkan pengguna internet, mendorong masyarakat untuk berkomunikasi dan melakukan kegiatan jual beli secara online. saat ini, online platform telah menjadi lading informasi yang digunakan untuk berbagi infromasi. Untuk itu, UMKM harus lebih memanfaatkan platform yang lebih terbuka yang akan mendorong pengembangan usaha. Platform bisnis online yang bersifat terbuka akan mendukung efektivitas implementasi hubungan antara ekonomi virtual dan ekonomi nyata melalui offline to omline. (2) Provide personalized experiences, yaitu salah satu sarana pemasaran yang efektif adalah rekomendasi personal yang mengacu pada pemberian informasi yang dilakukan personal untuk menarik minat beli konsumen. Keuntungan terbesar yang diraih perusahaan adalah ketika perusahaan dapat merekomendasikan produk sesuai dengan kebutuhan dan keinginan konsumen yang didasarkan pada preferensi yang didapatkan oleh perusahaan. (3) Strengthen personnel training, artinya sebelum memasuki dunia ecommerce, para pelaku usaha harus memperkuat dan mempertajam kemampuan dalam menguasai media digital. Pelaku usaha dapat mengikuti program pelatihan seperti workshop, seminar, maupun pelatihanan lain yang berkaitan dengan e-commerce. (4) Safeguard transaction security, artinya kenyamanan dan keamanan bertransaksi 
merupakan faktor utama yang diinginkan oleh konsumen.

\section{Penjualan}

Laba sutau bisnis dihasilkan dari aktivitas penjualan. Oleh karena itu, penjualan merupakan indikator terpenting yang menentukan perkembangan suatu bisnis. Penjualan merupakan faktor kunci dalam sebuah usaha. Dengan adanya penjualan suatu perusahaan atau apapun bentuk tempat usahanya pasti akan dapat bertahan (Tan, 2013).

Indikator dari penjualan menurut (Swastha, 2018) adalah (1) Mencapai volume penjualan tertentu, yaitu pentingnya menciptakan kerja sama antara pihak - pihak yang terkait dalam usaha. (2) Mendapatkan laba, yaitu tujuan dari dilakukannya penjualan adalah memperoleh laba yang realistis. (3) Menunjang pertumbuhan usaha, yaitu suatu kegiatan penjualan dapat dikatakan berhasil apabila usaha tersebut dapat tumbuh dan berkembang.

\section{Usaha Mikro, Kecil, dan Menengah}

UMKM memiliki definisi yang berbeda beda di berbagai negara. Di Indonesia sendiri, UMKM memiliki definisi secara terpisah. Usaha Mikro adalah usaha produktif milik orang perorangan dan/atau badan usaha perorangan yang memenuhi kriteria Usaha Mikro. Usaha Kecil adalah usaha ekonomi produktif yang berdiri sendiri, yang dialkukan oleh orang perorangan atau badan usaha yang bukan merupakan anak perusahaan atau bukan cabang perusahaan yang dimiliki, dikuasai, atau menjadi bagian baik angsung maupun tidak langsung dari Usaha Menengah atau Usaha Besar yang memenuhi kriteria Usaha Kecil. Usaha Menengah adalah usaha ekonomi produktif yang berdiri sendiri, yang dilakukan oleh orang perorangan atau badan usaha yang bukan merupakan anak perusahaan atau cabang perusahaan yang dimiliki, dikauasi, atau menjadi bagian baik langsung maupun tidak langsung dengan Usaha Kecil atau Usaha
Besar dengan jumlah kekayaan bersih atau hasil penjualan tahunan (UU No. 20 Tahun 2008, 2008).

Usaha Mikro, Kecil dan Menengah (UMKM) merupakan jenis usaha yang berperan penting dalam petumbuhan ekonomi suatu negara. UMKM pada umumnya dimiliki oleh perorangan.

Usaha Mikro, Kecil, dan Menengah dibagi menjadi beberapa jenis, salah satunya adalah kuliner. UMKM kuliner artinya usaha yang bergerak pada segalah hal yang meliputi makanan baik berat maupun ringan, serta minuman.

\section{Aplikasi BadokanGresik.id}

Salah satu platform digital lokal Gresik yang dapat digunakan untuk mendukung implemntasi strategi Offline to Online (O2O) adalah aplikasi BadokanGresik.id. Aplikasi ini diciptakan oleh Mamad Simatupang sebagai bentuk dukungan kepada UMKM Gresik yang terdampak wabah Covid-19. Apilkasi ini sudah aktif sejak Juni 2020 dan dirilis pada bulan November 2020. Tercatat UMKM kuliner yang telah menjadi mitra mencapai 73 UMKM. Aplikasi BadokanGresik.id merupakan bentuk dari mobile platform $\mathrm{O} 2 \mathrm{O}$ lokal pertama di kota Gresik.

\section{Penelitian Terdahulu}

Penelitian mengenai strategi O2O sudah banyak dilakukan. Pada penelitian yang dilakukan oleh Zhang et al. (2019) mengenai penambahan O2O Service Platform (O2OSP) pada bisnis offline menunjukkan hasil bahwa O2OSP terbukti mampu meningkatkan total penjualan dan keuntungan. Subyek yang dipilih pada penelitian tersebut yaitu restoran cepat saji di China. Sedangkan pada penelitian (Wardhanie et al. 2018) tentang pertumbuhan bisnis UMKM yang menggunakan strategi O2O menunjukkan hasil bahwa model bisnis O2O memiliki prospek yang besar dalam mengembangkan bisnis UMKM. 


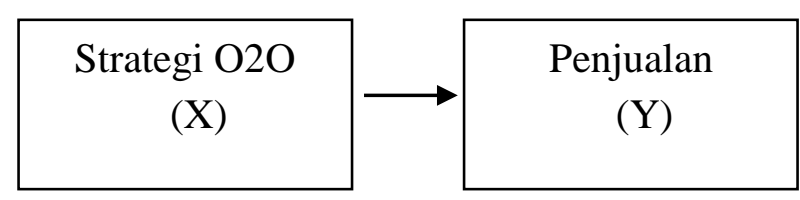

Gambar 2. Rancangan Penelitian

Berdasarkan paparan diatas, maka hipotesis penelitian adalah:

$\mathrm{H1}$ : Strategi Offline to Online (O2O) berpengaruh terhadap penjualan UMKM

\section{METODE PENELITIAN}

\section{Sumber Data}

Jenis penelitian yang digunakan adalah penelitian kuantitatif deskriptif. Adapun yang menjadi lokasi penelitian yaitu kota Gresik yang mencakup Kecamatan Gresik, Kecamatan Kebomas, dan Kecamatan Manyar. Populasi yang digunakan yaitu UMKM mitra aplikasi BadokanGresik.id sebanyak 73 UMKM. Banyaknya sampel dihitung menggunakan rumus Slovin, sehingga diperoleh hasil 62 UMKM. Data dihimpun menggunakan kuesioner online dengan bantuan Google Form (https://forms.gle/XbNPjaQquJ3TJDFZA).

Kuesioner disusun menggunakan skala Likert, yang mencakup lima poin skala pengukuran. Pengolahan hasil kuesioner menggunakan SPSS versi 25, menghasilkan data sebagai berikut.

\section{Defisini Operasional dan Pengukuran Variabel}

1. Penjualan

Penjualan adalah aktivitas menjual produk atau jasa guna memperoleh pendapatan. Terdapat indikator penjualan sebagai berikut:
a) Mencapai volume penjualan tertentu
b) Mendapat laba tertentu
c) Menunjang pertumbuhan perusahaan

2. Strategi Offline to Online $(\mathrm{O} 2 \mathrm{O})$

$$
\text { Strategi Offline to Online }(\mathrm{O} 2 \mathrm{O})
$$
adalah sebuah strategi bisnis yang mengkombinasikan online dalam memasarkan produk dan mendorong konsumen untuk melakukan transaksi pada toko fisik (offline). Terdapat indikator stategi Offline to Online (O2O) sebagai berikut:
a) Build network platform
b) Provide personalized experience
c) Strengthen personnel training
d) Safeguard transaction security

\section{HASIL DAN PEMBAHASAN}

\section{Karakteristik Responden}

Karakteristik responden dari hasil kuesioner terhimpun adalah:

Tabel 2. Karakteristik Responden

\begin{tabular}{lll}
\hline Karakteristik & Jumlah & $\begin{array}{l}\text { Persentase } \\
(\%)\end{array}$ \\
\hline $\begin{array}{l}\text { Umur Usaha } \\
<\text { 1tahun }\end{array}$ & 34 & $55 \%$ \\
$\begin{array}{l}\text { 1-5 tahun } \\
>\mathbf{5} \text { tahun }\end{array}$ & 23 & $37 \%$ \\
\hline $\begin{array}{l}\text { Kawasan Usaha } \\
\text { Kecamatan } \\
\text { Gresik }\end{array}$ & $5 \%$ & $41 \%$ \\
\hline $\begin{array}{l}\text { Kecamatan } \\
\text { Kebomas }\end{array}$ & 25 & $32 \%$ \\
\hline $\begin{array}{l}\text { Kecamatan } \\
\text { Manyar }\end{array}$ & 17 & $27 \%$ \\
\hline $\begin{array}{l}\text { Durasi menjadi } \\
\text { Mitra } \\
<\text { bulan }\end{array}$ & 20 & $32 \%$ \\
\hline 1-3 bulan & 30 & $48 \%$ \\
\hline$>$ 3bulan & 12 & $20 \%$ \\
\hline
\end{tabular}

Sumber: data diolah peneliti, 2021

Berdasarkan tabel 2, diketahui responden (pelaku UMKM) yang umur usahanya kurang dari 1 tahun berjumlah 34 atau 55\%, 1 - 5 tahun berjumlah 23 atau 37\%, dan diatas 5 tahun sebanyak 5 atau 8\%. Dilihat dari kawasan usahanya, menunjukkan bahwa dari total responden (pelaku UMKM), sebanyak 25 atau $41 \%$ berada di Kecamatan Gresik, sebanyak 20 atau $32 \%$ berada di Kecamatan Kebomas, dan sebanyak 17 atau $27 \%$ berada di Kecamatan Manyar. 
Berdasarkan kriteria durasi menjadi mitra, menunjukkan bahwa responden yang telah menjadi mitra aplikasi BadokanGresik.id kurang dari 1 bulan adalah sebanyak 20 atau $32 \%, 1$ - 3 bulan sebanyak 30 atau $48 \%$, dan lebih dari 3 bulan sebanyak 12 atau $20 \%$.

\subsection{Hasil Analisis Data}

Hasil olah data menggunakan SPSS 25 menghasilkan nilai persamaan regresi yaitu:

$$
\begin{aligned}
& Y=a+b X \\
& Y=0,254+0,874 X
\end{aligned}
$$

Keterangan:

$$
\begin{array}{ll}
\mathrm{Y} & =\text { Penjualan } \\
\mathrm{X} & =\text { Strategi } \mathrm{O} 2 \mathrm{O}
\end{array}
$$

Diketahui nilai koefisien regresi adalah bernilai positif yaitu 0,874 . Artinya, variabel strategi $\mathrm{O} 2 \mathrm{O}$ memberikan pengaruh positif terhadap variabel penjualan.

Tabel 3. Uji Koefisien Determinasi

\begin{tabular}{ll}
\hline $\mathrm{R}$ Square & Adjusted $R$ square \\
\hline 0,511 & 0,503 \\
\hline
\end{tabular}

(Sumber: data diolah peneliti, 2021)

Pada tabel 3, diketahui nilai koefisien determinasi $\left(\mathrm{R}^{2}\right)$ yaitu 0,503 . Angka tersebut menyatakan variabel $\mathrm{X}$ berpengaruh sebesar $50,3 \%$ terhadap variabel $\mathrm{Y}$, sedangkan $49,7 \%$ sisanya dipengaruhi variabel lain yang tidak dibahas dalam penelitian ini.

\subsection{Hasil Uji Hipotesis}

Tabel 4. Uji F Strategi O2O

\begin{tabular}{lll}
\hline Variabel & F & Sig. \\
\hline Regression & 62,802 & 0,000 \\
\hline
\end{tabular}

Sumber: data diolah peneliti, 2021

Tabel 4 menunjukkan bahwa $\mathrm{F}$ hitung yang diperoleh yaitu 62,802 (lebih besar daripada Ftabel yakni 1,99) dengan nilai sig. $0,02<0,05$. Maka dinyatakan strategi Offline to Online $(\mathrm{O} 2 \mathrm{O})(\mathrm{X})$ memiliki pengaruh secara simultan terhadap penjualan (Y).

Dari hasil uji F, dapat diketahui bahwa penjualan dapat meningkat apabila diterapkan strategi Offline to Online $(\mathrm{O} 2 \mathrm{O})$. Terdapat beberapa indikator yang memberikan penilaian , yaitu: (1) Build network platform: UMKM dapat memanfaatkan aplikasi atau online platform yang bersifat terbuka seperti aplikasi BadokanGresik.id. Pada indikator ini, hasil angket menunjukkan nilai rata - rata jawaban tertinggi yaitu sebesar 4,73. (2) Provide personalized experiences: dengan memberikan pengalaman menjual dengan strategi $\mathrm{O} 2 \mathrm{O}$, responden setuju bahwa aplikasi BadokanGresik.id melayani transaksi penjualan yang praktis dan cepat, sehingga dapat menciptakan pengalaman yang sesuai dengan yang diharapkan oleh responden. Hasil angket menunjukkan nilai rata - rata sebesar 4,53. (3) Strengthen personal training: keahlian dalam menjual produk secara online dan offline perlu ditingkatkan dalam menerapkan strategi O2O. Pada indikator ini, responden setuju bahwa keahlian menjual produk dan pelayanan dapat ditingkatkan dengan melalui aplikasi BadokanGresik.id. Hasil angket menunjukkan nilai rata - rata sebesar 4,50. (4) Safeguard transaction security: online platform harus dapat menjamin keamanan bertransaksi dan menyediakan beberapa pilihan metode pembayaran. Pada indikator ini, responden setuju bahwa aplikasi BadokanGresik.id dapat menjamin keamanan dan memberikan pilihan metode pembayaran sehingga penerapan strategi Offline to Online $(\mathrm{O} 2 \mathrm{O})$ dapat berjalan sesuai yang diharapkan. Hasil angket menunjukkan angka 4,44.

Berdasarkan jawaban yang telah dihimpun, nilai rata-rata terbesar adalah pernyataan nomor 2 yang menyatakan bahwa aplikasi BadokanGresik.id bersifat terbuka dan dapat diakses oleh siapapun. Sehingga dapat ditarik kesimpulan bahwa strategi Offline to Online $(\mathrm{O} 2 \mathrm{O})$ dapat diterapkan dengan bantuan aplikasi BadokanGresik.id.

Pernyataan nomor 7 merupakan pernyataan dengan nilai terendah yaitu sbeesar 4,25 yang menyatakan bahwa aplikasi BadokanGresik.id menyediakan pilihan metode pembayaran. Maka, dapat disimpulkan bahwa aplikasi BadokanGresik.id tidak 
menyediakan banyak pilihan metode pembayaran.

Pada variabel penjualan, nilai rata rata tertinggi terletak pada nomor 7 yaitu sebesar 4,62 yang menyatakan bahwa pangsa pasar lebih luas setelah menerapkan strategi O2O melalui aplikasi BadokanGresik.id. Sedangkan nilai rata - rata terendah terletak pada nomor 2 yaitu sebesar 4,17 yang menyatakan bahwa volume penjualan meningkat setelah menerapkan strategi $\mathrm{O} 2 \mathrm{O}$ melalui aplikasi BadokanGresik.id. Sehingga dapat disimpulkan bahwa volume penjualan UMKM tidak mengalami peningkatan yang tinggi setelah menerapkan strategi $\mathrm{O} 2 \mathrm{O}$ melalui aplikasi BadokanGresik.id.

Berdasarkan data terhimpun yang telah diolah, dapat disimpulkan jika variabel strategi Offline to Online $(\mathrm{O} 2 \mathrm{O})$ berpengaruh secara signifikan terhadap variabel penjualan UMKM mitra aplikasi BadokanGresik.id. Strategi Offline to Online $(\mathrm{O} 2 \mathrm{O})$ cocok untuk diterapkan Usaha Mikro Kecil dan Menengah guna membantu tercapainya tujuan penjualan. Hasil dari penelitian ini mendukung hasil dari penelitian sebelumnya dengan responden yang sama yaitu UMKM, dimana strategi Offline to Online (O2O) berpengaruh terhadap peningkatan penjualan sehingga menghasilkan keuntungan dan usaha dapat lebih berkembang.

\section{KESIMPULAN DAN SARAN}

Dari hasil penelitian mengenai strategi Offline to Online $(\mathrm{O} 2 \mathrm{O})$ pada UMKM mitra aplikasi BadokanGresik.id, maka dapat diambil kesimpulan hasil analisa bahwa variabel strategi Offline to Online $(\mathrm{O} 2 \mathrm{O})(\mathrm{X})$ berpengaruh secara signifikan dan positif terhadap penjualan UMKM mitra aplikasi BadokanGresik.id (Y) dengan nilai sig $0,000<0,05$ dan nilai $t$ hitung sebesar 7,795 $>\mathrm{t}$ tabel $(1,99)$. Hasil uji analisis linier sederhana menunjukkan korelasi antara strategi Offline to Online $(\mathrm{O} 2 \mathrm{O})$ dan penjualan $(\mathrm{Y})$ sangat kuat.

\section{Saran}

Penelitian ini memiliki kekurangan dan keterbatasan, salah satunya adalah jumlah variabel $X$ yang digunakan hanya satu pun juga variabel Y. untuk itu, disarankan untuk peneliti selanjutnya yang hendak mengangkat tema penelitian yang sama, mengangkat variabel lain pula dalam penelitiannya. Sehingga penelitian tersebut dapat lebih luas hasilnya.

\section{REFERENSI}

Aslamiyah, S. 2021. Formulasi Strategi Ukm Jilbab Azky Collection Untuk Meningkatkann Daya Saing Di Masa Pandemi Covid-19. Manajerial, 8(01), 102.

https://doi.org/10.30587/manajerial.v8i01 .2121

BPS. 2020. Kabupaten Gresik Dalam Angka 2020. Badan Pusat Statistik Kabupaten Gresik, 1-414.

Išoraitė, M., \& Miniotienè, N. 2018. Electronic Commerce: Theory and Practice Electronic Commerce: Theory and Practice. 91034.

Pradiani, T. 2018. Pengaruh Sistem Pemasaran Digital Marketing Terhadap Peningkatan Volume Penjualan Hasil Industri Rumahan. Jurnal Ilmiah Bisnis Dan Ekonomi Asia, 11(2), 46-53. https://doi.org/10.32812/jibeka.v11i2.45

Sulistyowati, R. 2020. Does Impact of Entrepreneurial Literacy and Digital Literacy on a Businessmen Who Influences the Strategy to Maintain SME in The Pandemic Era? Technium Social Sciences Journal, 6.

Swastha, B. 2018. Manajemen Penjualan (3rd ed.). BPFE-Yoyakarta.

Syafwendi. 2016. Analisis Pengaruh Citra Merek dan Strategi O2O (Online to Offline) Perusahaan E-commerce Terhadap Kepercayaan dan Dampaknya Pada Proses Keputusan Pembelian Konsumen dalam Jual-Beli Online (Studi 
Kasus Pada Pelanggan

MatahariMall.com). 2008(November),

187.

https://doi.org/10.13140/RG.2.2.35021.0

5604

Tan, A. 2013. Psikologi Penjualan.

UU No. 20 Tahun 2008. 2008. UU No. 20

Tahun 2008. UU No. 20 Tahun 2008, 1, $1-31$

Wang, Y. 2020. Research on the Application of Online-to-offline Mode in Agricultural Products E-Commerce Based on New Retail. 109(Icemci), 272-275. https://doi.org/10.2991/aebmr.k.191217.0 50

Xing, X., \& Zhu, J. 2014. The Study of O2O Business Model Development Strategy in SMEs. International Journal of Business and Social Science, 5(9), 296-299.

$\mathrm{Xu}, \mathrm{T}$. , \& Zhang, J. 2015. A Development Strategy of $\mathrm{O} 2 \mathrm{O}$ Business in China. Proceedings of the 2015 International Conference on Computer Science and Intelligent Communication, 16(Csic), 337-340. https://doi.org/10.2991/csic15.2015 .81 